\title{
Abnormal Returns, Corporate Financial Policies and the Dynamics of Leverage: Empirical Evidence from Non-Financial Sector of Pakistan
}

\author{
${ }^{a}$ Kashif Hamid, ${ }^{b}$ Zahid Hussain, ${ }^{c}$ Muhammad Mudasar Ghafoor \\ ${ }^{a}$ Faculty Member, IBMS,University of Agriculture Faisalabad.Email:kashif.boparai@hotmail.com \\ ${ }^{\mathrm{b}}$ Faculty Member, FMS, National Textile University, Faisalabad, Email: zahid@ntu.edu.pk \\ c Assistant Professor, University of the Punjab, Jhelum Campus, Jhelum. \\ Email: mudasar@pugc.edu.pk.com
}

\begin{tabular}{l}
\hline ARTICLE DETAILS \\
\hline History: \\
Accepted 19 March 2020 \\
Available Online 31 March 2020
\end{tabular}

\section{Keywords:}

Financial Leverage,

Total Leverage

WACC, Fixed Effect, Random

Effect, Robust

\section{JEL Classification:}

B26, D53, 047

DOI: $10.47067 /$ reads.v6i1.193

\begin{abstract}
The aim of this study is to evaluate impact of corporate financial policies and the dynamics of leverage on financial performance of non-financial sector in Pakistan. In this study we used the data from Fertilizer, Chemical and Cement sector for the period 2008-2017. Abnormal return has been taken as dependent variable and Change in cash to lagged market values, Change in EBIT to lagged market values, Change in dividend to lagged market value, Net Financing to lagged market value, Lagged cash values to lagged market values, Lagged cash values to lagged market values crossed by change in cash to lagged market value, Change in total assets net of cash to lagged market values, Change in interest to lagged market values, Operating leverage, Financial leverage, Total leverage, Leverage ratio, Leverage ratio to change in cash crossed by lagged market values and WACC are taken as explanatory variables. OLS, Fixed effect and Random effect models has been used to express the impact of these variables on return. Hence it is concluded that leverage dynamics are significant contributors in designing the corporate financial policies. Corporate financial policies have significant impact on the financial performance of the non-financial sector of Pakistan.
\end{abstract}

(C) 2020 The authors. Published by SPCRD Global Publishing. This is an open access article under the Creative Commons Attribution-

NonCommercial 4.0

\section{Introduction}

Downfall in industrial sector has become critical issue in the economy of Pakistan in recent years. These downfalls may be due to financial policies incorporated by the firms in a traditional manner. In first instance the core domains of leverage policies and its dynamics are discussed in a brief manner. Leverage is used to magnify the level of returns and the optimal level of leverage is a result of high integrated leverage policies of the firm. Leverage dynamics are changing dynamics and still have loop holes in the policies for strengthen the anatomy of the industrial structure of Pakistan economy. In business context the term leverage means a corporate debt used to finance the assets of a firm. Leverage can increase the firm's risk of bankruptcy as well as assist to enhance the abnormal 
returns of the firm. Leverage is classified into three domains as operating leverage, financial leverage and total leverage. Operating leverage is a ratio of fixed cost to variable cost. If a firm has high fixed costs as compared to variable costs then firm has high operating leverage. Operating leverage can also be interpreted as a change in EBIT to change in sales. If the result is greater than one then it means operating leverage exits in the business. Financial leverage means the amount of debt in capital structure of the firm. Huge amount of financial leverage can increase the risk of default and bankruptcy. The financial leverage is computed as percentage change in earning per share divided by the percentage change in EBIT. If the result of ratio is greater than one, then it shows the presence of financial leverage in the business.

Total leverage means the total amount of risk faced by a business firm and it is a combination of operating and financial leverage. Total leverage is calculated as percentage change in the earning per share divided by percentage change in sales. Total leverage is a result of multiplication of operating leverage and financial leverage. Further leverage ratio can affect a corporate risk, financing capacity, cost of capital, strategic decisions investment and finally shareholders wealth. Cai and Zhang (2011) used financial leverage ratio to identify the impact on firm stock price. Modigliani and Miller (1958), leverage ratios can also be affected by the many other elements additionally to the issuance of the security and share repurchase, including earnings accumulation, dividend payment, provision or use of trade credit or payment of existing credit line etc. In second instance a brief introduction of corporate financial policies is discussed as adopted by the firms. Such corporate financial polices include cash policies, earning management, dividend policies, asset management, capital structure and cost of capital policies. Cash management includes the sustainability of optimal level of the most liquid item in the current asset. Its change over the span of time indicates the ultimate requirement of the business unit but the excessive amount of cash indicates the precautionary needs. The earning management dilemma indicates the level of earnings after meeting the fixed and variable costs and how various policies regarding to the costing is used to enhance the profitability. Dividend policy may affect the market value behavior over the financial years. Whereas the asset management includes the total size of the firm and its sustainability over the span of time with best performing portfolio of current assets as well as fixed asset and its role in enhancing the returns on asset. Capital structure is the mix of long term debt and equity in the business financing portfolio. The optimal capital structure theory leads to the maximization of earnings before interest and taxes by reducing the weighted average cost of capital. Tangibility, size, profitability, market to book ratios have number of times been reported by different researchers that may affect the corporate financial policies. As Bhatti, Majeed, Rehman and Khan (2010) investigated the impact of leverage on systematic risk and stock returns for the industrial sector of Pakistan.

However, Cost of capital is the weighted-average of after tax cost of firm's long-term debt, common and preferred stock. Cost of capital is the rate of return which could be earned on an investment with the similar risk. It may also be defined from company as well as investor point of view. From company's point of view, the cost of capital refers to the cost of debt or equity to finance an investment. However from an investor point of view, the cost of capital is the required rate of return that an investment must provide to the business. Cost of capital is used as a bench mark parameter because it is used to evaluate the new projects of a firm, as well as it is the minimum return that investors expect for providing capital to the company.

A firm's securities typically include both equity and debt therefore one must calculate the cost of equity and the cost of debt both are necessary to determine a firm's cost of capital. A more important calculation of cost of capital is the (WACC) weighted average cost of capital. The purpose of this study is 
to investigate the relationship and to model the leverage dynamics and corporate financial policies for the abnormal returns of the firms. In this study we are focusing to investigate the changing dynamics of explanatory variables on the firm's abnormal returns to optimize the best corporate financial policies for the industrial sector Pakistan. This study will contribute in designing the optimal mix of strategic financial policies to identify the key elements that may magnify the returns level.

\section{Literature Review}

Aivazian, Ge and Qiu (2005) examined the effect of financial leverage on the firm's investment decisions and concluded that there exist negative association between leverage and $h$ investment decisions. The outcomes support the agency theory for corporate leverage and its disciplinary role for lower growth firms. Dangl and Zechner (2006) investigated that long term debt maturities abolish share holders' incentives and decrease in leverage leads to poor corporate performance. Whereas short term debt maturity increases shareholders interest due to declines in leverage. However, a short debt maturity increases the transactions costs. They identified the tradeoff between the higher expected transactions costs against the commitment to decrease the leverage when the company is performing poorly. Therefore it motivates towards an optimum maturity structure of the corporate debt. Debt maturity requires the suitable level of financial leverage to reduce the volatility of the cash flows of the firm. They also found that the share holders' incentives to decrease the debt are non-monotonic in the presence of corporate leverage. If the firm is pressed towards bankruptcy by a determined series of low cash flows, then ownership can start again issuing the debt to refinance the maturity bonds.

Abdullah, Aydemir, Gallmeryer and Hollifield (2006) studied the impact of financial leverage on market portfolio of small companies with market risk. In an economy with both constant price of risk and a constant interest rate, financial leverage creates small difference in share return volatility at the level of market but significant deviation at the individual level of the firm. In an economy having more realistic deviation in the price of risk and interest rates, there is a significant variation in the return volatility at firm as well as at market level. In such economies, financial leverage has less impact upon the dynamics of returns volatility at market level. Financial leverage increases more stock returns volatility on small size firm. Maia (2010) investigated the relationship between the expected equity returns, capital structure determinants and the financial leverage of the firms. It is concluded that firms having lower leverage leads to a higher discount-rate of beta and firms with high leverage is related to lower cash-flow of beta. Moreover the key determinants of the corporate capital structures are associated with the firm's sensitivities due to systematic risk and are significantly important for high and low leveraged firms. The study reveals that short-term shocks are comparatively more important for the firms having low leverage and financial risk is more sensitive to the firm's cash flow.

Bhatti, Majeed, Rehman and Khan (2010) investigated the Cotton, Chemical, Engineering, Sugar, Cement, Fuel \& Energy, Communication and transport industries sector and concluded that high level of leverage in these industries cause higher level of systematic risk as well as high volatility in the stock prices. Cai and Zhang (2011) documented a negative and significant impact of change in a firm's leverage ratio on the firm's stock prices. They found that the negative effect is very stronger for that firms which have higher leverage ratio, face more severe financial constraints and have higher likelihood of default. Moreover, firms which have an increase in the leverage ratio tend to have low future investment. These results are constant with debt overhang theory which tells us that an increase in the leverage may leads to the future underinvestment, thus decrease in the value of a firm. Johnson, Chebonenko, Cunha, D'Almeida and Spencer (2011) examined the endogenous choice conditions of debt which persuades a negative relationship between the leverage and the expected stock returns. 
Faulkender, Flannery, Hankins and Smith (2012) explored that the cash flow realizations can provide opportunities to the firm to adjust the leverage at the lower marginal cost. They found that a firm's cash flows attributes are not only affect the leverage target, but also speed of the adjustment towards those targets. Adjustment speeds is driven by an economical concept of adjustment costs. Further they investigate that how market timing and financial constraints affect the adjustments towards a leverage target. Obreja (2013) suggested a new dynamic model for the corporate sector that associates operating leverage to both book-leverage premium and value premium in stock returns. Due to which the book-leverage premium become negative while the value premium becomes positive. Without the operating leverage, the symbols of both premiums are reversed therefore this model has quantitatively many important for cross-section stock returns.

Yarram (2013b) identified positive relation between ownership concentration and leverage. The study used data for 465 firms during the period 2004 to 2010. Frank and Goyal (2015) identified the serious defect in the trade-off theory due to contrary relation between leverage and profitability. Study reveals that the theory is not defected but by applying a leverage ratio in which profitability influence both the numerator and denominator. Firms have taken the offsetting actions for predictions. When profitability increases firms issue debt and repurchase equity, and repay debt and issue equity capital when profitability declines. Consistency with varying transactions costs, to fully undo the profitability shocks; therefore such adjustments are not generally sufficient. However on an average the leverage ratio falls as profitability increases. Ball, Gerakos, Linnainmaa and Nikolaev (2016) reported that adjusted cash flows create a profit measure mainly unchanged by the timing of payments and receipts of cash. They identified that prior research do not cover expected returns which may rise in profitability and fall in accruals.

Riccetti, Russo and Gallegati (2016) developed a model which has three main financial accelerators: leverage, stock market and network. The leverage effect shows negative shocks over the firm's output as a result of banking sector which is less willing for loans. Moreover, firms has less willing for the further investment and therefore the credit reduction more reducing the outputs. Due to the stock market effect lower profit over stock returns which reduces the firm's capitalization on the stock market. The credit network may be transmitting the initial shock. They concluded that if the stock market is the main indicator of economy then variation in the stock market may destruction real economy. The result has relevant implications for the monetary policy.

Teng, Si and Hachiya (2016) analyzed the leverage-return dilemma and observe the returns affect due to bank debts by considering the capital structure heterogeneity and dynamic nature. The relative leverage examined that the returns has strong and positive relationship with leverage. The positive relationship may be partially described in the way that the relative components may negatively forecast the prospect asset growth or may contain considerable information about the future risk.

Nadarajah, Ali, Liu and Haung (2016) examined the effect of corporate governance and the stock liquidity over the firm's leverage decisions in order to drive for the stock trading system and less severe for Australian governance environment. The non-financial sector data is taken for 1207 firms during the period of 2001-2013. The outcomes indicate that the negative stock relationship exist between the liquidity and leverage. The results support the past research, which the firms having more liquid stocks have significantly less leveraged. The outcome also indicates that the significant negative relationship exists between leverage and corporate governance quality, which shows that the firms having high corporate governance quality significantly decrease leverage.

Duan et al, (2018) investigated the impact of leverage effect and uncertainty of economic policy 
on the future volatility in the regime switching framework. The results of this study indicate that the HAR-RV having the leverage effect and uncertainty of economic policy with regimes can get higher forecast accuracy than GARCH and RV-type models. Moreover the results of this study show that these factors in regime switching framework can substantially increase the performance of HAR-RV's forecast. Admati et al, (2018) studied the firms' incapability to commit to future funding choices has thoughtful results for capital structure dynamics. With debt, shareholders resist leverage reductions pervasively without considering how much these reductions may increase the value of firm. The choices of leverage can have the implication for shareholders value. Shareholder value reduced due to new debt threat of bankruptcy and asymmetric behavior. The asymmetric behavior makes leverage adjustment just through arbitraging process.

\subsection{Hypothesis}

H1: Change in cash to lagged market values has a negative impact on abnormal return and has a significant positive relationship with abnormal return.

H2: $\quad$ Change in EBIT to lagged market values has a positive impact on abnormal return and has a significant positive relationship with abnormal return.

H3: Change in dividend to lagged market values has a positive impact on abnormal return and also has a significant positive relationship with abnormal return

H4: Net Financing to lagged market values has a positive impact on abnormal return and also has a significant negative relationship with abnormal return.

H5: Lagged cash values to lagged market values has a positive impact on abnormal return and also has a significant positive relationship with abnormal return.

H6: Lagged cash values to lagged market values crossed by change in cash to lagged market value has a positive impact on abnormal return and also has a significant negative relationship with abnormal return.

H7: Change in total assets net of cash to lagged market values has positive impact on abnormal return and also has a significant positive relationship with abnormal return.

H8: Change in interest to lagged market values has negative impact on abnormal return and also has a significant negative relationship with abnormal return.

H9: Operating leverage has positive impact on abnormal return and also has a significant negative relationship with abnormal return.

H10: Financial leverage has a positive impact on abnormal return and also has significant negative relationship with abnormal return.

H11: Total leverage has a positive impact on abnormal return and also has significant negative relationship with abnormal return.

H12: Leverage ratio has a positive impact on abnormal return and also has significant negative relationship with abnormal return.

H13: Leverage ratio to change in cash crossed by lagged market values has a positive impact on abnormal return and also has significant negative relationship with abnormal return.

H14: WACC has a positive impact on abnormal return and also has significant negative relationship with abnormal return.

\section{Data and Methodology}

In this study we used the data for the Chemical, Cement and Fertilizer sector during the period 2008-2017. These sectors consist of 42 companies which are registered at Karachi Stock Exchange (KSE). The data has been taken from the official website of the State bank of Pakistan. We deployed descriptive statistics, correlation, ordinary least squares model, Fixed and Random Effect Models to analyze the data. 


\subsection{Model Specifications}

To explore the impact of leverage dynamics and corporate financial policies on abnormal returns the model is identified in this manner.

Model: Effect of Leverage Dynamics and Corporate Financial Policies on Abnormal Return.

Abnormal Return $=\mathrm{f}$ (Change in cash to lagged market values, Change in EBIT to lagged market values, Change in dividend to lagged market value, Net Financing to lagged market value, Lagged cash values to lagged market values, Lagged cash values to lagged market values crossed by change in cash to lagged market value, change in total assets net of cash to lagged market values, Change in interest to lagged market values, Operating leverage, Financial leverage, Total leverage, Leverage ratio, Leverage ratio to change in cash crossed by lagged market values and WACC)

Regression Equation for Effect of Leverage Dynamics and Corporate Financial Policies on Abnormal Return:

$\mathrm{AR} \mathrm{i,t}=\alpha_{0}+\alpha_{1} \quad \Delta \mathrm{C} / \mathrm{Mt}-1+\alpha_{2} \Delta \mathrm{EBIT} / \mathrm{Mt}-1+\alpha_{3} \Delta \mathrm{D} / \mathrm{Mt}-1+\alpha_{4} \mathrm{NF} / \mathrm{Mt}-1+\alpha_{5} \mathrm{Ct}-1 / \mathrm{Mt}-1+\alpha 6[\mathrm{Ct}-1$ $/ \mathrm{Mt}-1] \times[\Delta \mathrm{C} / \mathrm{Mt}-1]+\alpha 7 \Delta \mathrm{NA} / \mathrm{Mt}-1 \alpha 8 \Delta \mathrm{I} / \mathrm{Mt}-1+\alpha 9 \mathrm{DOL}+\alpha 10 \mathrm{DFL}+\alpha 11 \mathrm{DTL}+\alpha 12 \mathrm{LR}+\alpha 13 \mathrm{LR}$ $/[\Delta \mathrm{C} \times \mathrm{Mt}-1]+\alpha_{14} \mathrm{WACC}+\dot{\varepsilon}$

Whereas, $\mathrm{AR}=$ Abnormal Return, $\Delta \mathrm{C} / \mathrm{Mt}-1=$ Change in cash to lagged market values, $\Delta \mathrm{EBIT}$ /Mt-1 = Change in EBIT to lagged market values, $\Delta \mathrm{D} / \mathrm{Mt}-1=$ Change in dividend to lagged market values, $\mathrm{NF} / \mathrm{Mt}-1=$ Net Financing to lagged market values, Ct-1 / Mt-1 = Lagged cash values to lagged market values, $[\mathrm{Ct}-1 / \mathrm{Mt}-1] \times[\Delta \mathrm{C} / \mathrm{Mt}-1]=$ Lagged cash values to lagged market values crossed by change in cash to lagged market values, $\Delta \mathrm{NA} / \mathrm{Mt}-1=$ Change in total assets net of cash to lagged market values, $\Delta \mathrm{I} / \mathrm{Mt}-1=$ Change in interest to lagged market values, $\mathrm{DOL}=$ Operating Leverage, $\mathrm{DFL}$ $=$ Financial Leverage, DTL $=$ Total Leverage, $\mathrm{LR}=$ Leverage Ratio

$\mathrm{LR} /[\Delta \mathrm{C} \times \mathrm{Mt}-1]=$ Leverage ratio to change in cash crossed by lagged market values, WACC $=$ Weighted average cost of capital

Simple linear model in a static level is expressed in the manner below:

whereas $\mathrm{i}=1, \ldots \mathrm{N}$ and $\mathrm{t}=1, \ldots, \mathrm{T}$

$$
\mathrm{Y}_{\mathrm{it}}=\varphi+\mathrm{x}_{1} \delta_{1}+\mathrm{x}_{2} \delta_{2}+\cdots+\mathrm{x}_{\mathrm{n}} \delta_{\mathrm{n}}+\varepsilon_{\mathrm{t}}
$$

$\mathrm{Y}_{\mathrm{it}}=$ Abnormal Return for company $\mathrm{i}$ in year $\mathrm{t}$

$\mathrm{X}_{\mathrm{it}}=$ Vector of time varying regressors.

$\varphi_{\mathrm{i}}=$ Individual effects or Constant or an unobserve heterogenety

$\varepsilon_{i t}=$ Error term independent and identical distribution having zero mean variance value

Cross section regression will produce a biased estimate of beta coefficient if there exist correlation between $\varepsilon_{i t}$ and xit. Therefore it is necessary to identify whether the unobserved individual effects $\varepsilon_{i t}$ are random or fixed. There exist two basic methods for this model. The fixed effects method take $\varepsilon_{\text {it }}$ to be a group specific constant regarding to the regression model. On the other hand random effects method specifies that $\varepsilon_{\mathrm{it}}$ is a group specific disturbance.

\subsection{Fixed Effects Model}

Fixed effects model indicates a constant slope but differ in intercepts in comparison to crosssectional firms. Fixed effect model controls the potential correlation between the regressors and 
unobservable individual effects. However the fixed effects method takes $\varepsilon_{i t}$ to be a group specific constant term in regression model.

Fixed effect model is narrated as below:

$$
\mathrm{Y}=\varphi+\beta^{\prime} \mathrm{x}+\dot{\varepsilon}: \mathrm{i}=1,2, \ldots, \mathrm{N} \text { and } \mathrm{t}=1,2, \ldots, \mathrm{T}
$$

In the case of the presence of fixed effects, $\beta$ and $\varphi_{i}$ can be estimated consistently and efficiently by the Within Groups estimators (WG) attained from OLS equation.

$$
\overline{\mathrm{Y}}=\frac{1}{\mathrm{~T}} \sum_{1}^{\mathrm{T}} \overline{\mathrm{y}} \quad: \quad \overline{\mathrm{x}}=\sum_{1}^{\mathrm{T}} \overline{\mathrm{y}} \quad \text { and } \quad \grave{\varepsilon}=\frac{1}{\mathrm{~T}} \sum_{1}^{\mathrm{T}} \grave{\varepsilon}
$$

Then,

$$
Y=\varphi+\beta^{\prime} x+\grave{\varepsilon}
$$

Subtracting this equation from equation to get:

$$
\begin{gathered}
(Y-\bar{Y})=\beta^{\prime}(x-\bar{x})+(u-\ddot{\bar{u}})(4) \\
\bar{Y}=\left(\beta^{\prime} \bar{x}+\ddot{\bar{u}}\right) \quad \text { for } t=1, \ldots \ldots \ldots, T
\end{gathered}
$$

Pooled ordinary least square can be used to the transformed model to estimate $\beta$ in a natural phenomenon and (WG) can also be used to eliminate any time-invariant variable in this model. It is because that $\varphi$ is taken as fixed constant, and the estimator of $\beta$ is known as ( $\beta \mathrm{wg}$ ).

$$
\mathrm{B}_{\mathrm{wg}}=\left[\sum_{1}^{\mathrm{N}} \sum_{1}^{\mathrm{T}}\left(\mathrm{x}_{\mathrm{it}}-\overline{\mathrm{x}}_{\mathrm{it}}\right)\left(\mathrm{x}_{\mathrm{it}}-\overline{\mathrm{x}}_{\mathrm{it}}\right)\right]^{-1}\left[\sum_{1}^{\mathrm{N}} \sum_{1}^{\mathrm{T}}\left(\mathrm{x}_{\mathrm{it}}-\overline{\mathrm{x}}_{\mathrm{it}}\right)\left(\mathrm{x}_{\mathrm{it}}-\overline{\mathrm{x}}_{\mathrm{it}}\right)\right]
$$

The fixed effect estimators are given by:

$$
\widehat{\gamma_{1}}=\square-\bar{x}_{\mathrm{t}} \widehat{\beta w} g
$$

One of the biggest advantages of the FE model is that the error terms may be related with the individual effects of the model. On the other hand if the group effects are unrelated with group means of the regressors, it is better to apply a thriftier parameterization of the panel model.

\subsection{Random Effect Model}

The random effects model is a regression equation with a random constant term. A specific effect is visualized as an outcome of a random variable. In simple terms, a static random effects model may be explained as below.

$$
\begin{aligned}
& y_{i t}=\beta^{\prime} x_{i t}+v_{i t} \\
& v_{i t}=\gamma_{i}+\mu_{i t}
\end{aligned}
$$

Where $\mu_{\mathrm{it}}$ is independent and identical distribution such that:

$$
\begin{gathered}
\left(-E\left(\gamma_{i}\right)=E\left(\mu_{i t}\right)=0\right. \\
\left(-E\left(\gamma_{i} \mu_{i t}\right)=0\right. \\
-E\left(\boldsymbol{\gamma}_{\mathbf{i}}, \boldsymbol{\gamma}_{\mathbf{j}}\right)=\left\{\begin{array}{cc}
\boldsymbol{\sigma}^{2} & \mathbf{i}=\mathbf{j} \\
\mathbf{0} & \mathbf{i} \neq \mathbf{j}\}
\end{array}\right\} \\
-E\left(\mu_{\mathrm{it}}, \mu_{\mathrm{js}}\right)=\left\{\begin{array}{cc}
\sigma^{2} & \mathrm{i}=\mathrm{j}, \mathrm{i}=\mathrm{j} \\
0 & \mathrm{i} \neq \mathrm{j}, \mathrm{i} \neq \mathrm{j}
\end{array}\right\} \\
-E\left(\gamma_{\mathrm{i}}, \mathrm{x}_{\mathrm{it}}\right)=\left(\mu_{\mathrm{it}}, \mathrm{x}_{\mathrm{it}}\right)=\mathrm{o}
\end{gathered}
$$


The appropriate GLS estimator of $\beta$ shows that the random estimator, given by $\beta_{\mathrm{GLS}}$ is consistent.

\section{Results and discussion \\ 4.1 Descriptive Statistics}

Table 1 indicates that the returns are positive i.e. 0.005 in chemical sector along with 1.319 standard deviation. Whereas Table 2 indicates that returns are -0.0022 along with 1.22234 standard deviation. More over Table 3 indicates also negative abnormal returns which are -0.0106 in fertilizer sector along with 1.2234 standard deviation. So the return behavior is different in each sector. It can be visualized in the figure 1. This figure indicates that cement sector is more growing sector in Pakistan and providing high abnormal returns that chemical and fertilizer sector. However each sector has now streamlined the abnormal returns in positive domain.

\section{Figure 1: Average Abnormal Returns}

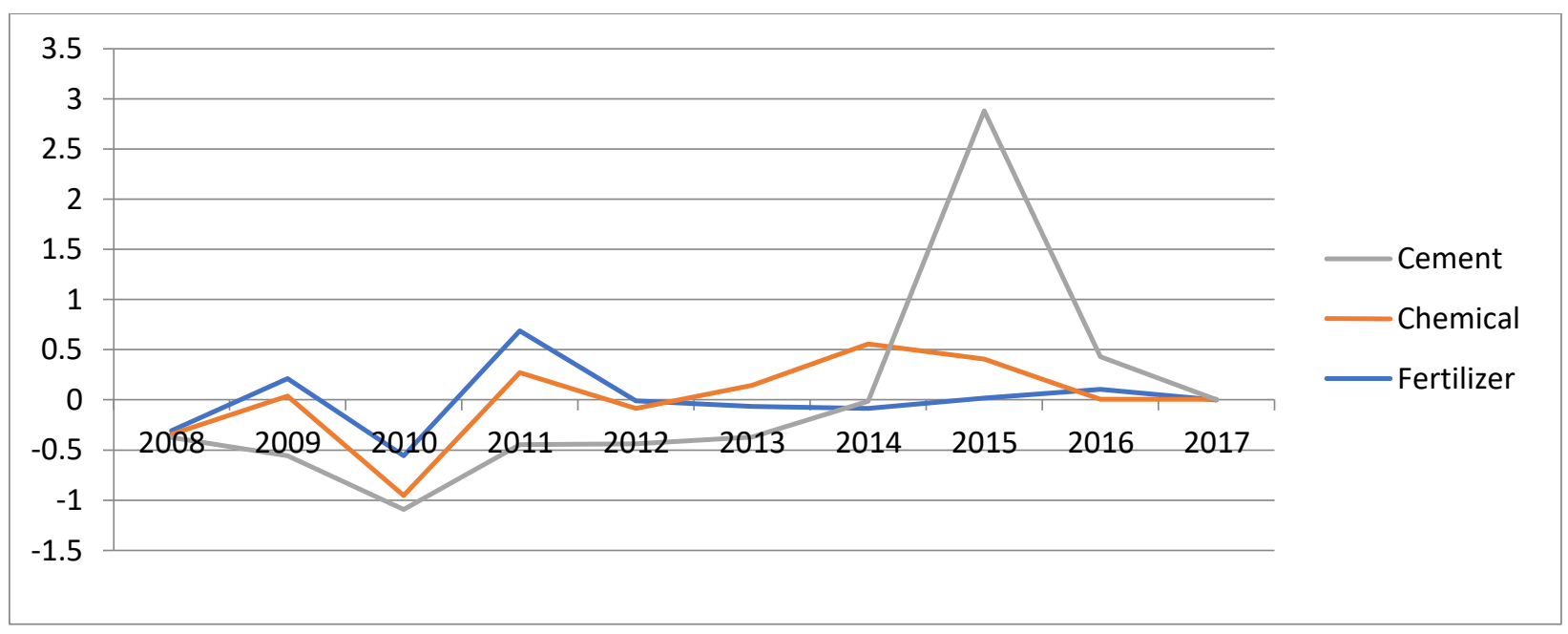

Table 1 Descriptive Statistics of Chemical Sector

\begin{tabular}{|c|c|c|c|c|c|c|c|c|c|c|c|c|c|c|c|}
\hline & $\mathrm{AR}$ & CCMt & CEBItMt & CDMt & NFMt & CtMt & CtMtCCMt & CACMt & CIMt & $\mathrm{OL}$ & $\mathrm{FL}$ & TL & LR & LRCCMt & WACC \\
\hline Mean & 0.005 & 0.135 & 0.097 & 0.081 & 835991.625 & 79634.6647 & 17047.49194 & 0.02752 & 0.38509 & $\begin{array}{l}-199.06216 \\
\end{array}$ & -18.463 & -3578.0595 & 0.172 & -16.289 & 254396.87 \\
\hline $\begin{array}{l}\text { Standard } \\
\text { Error }\end{array}$ & $0.09 \mathrm{c}$ & 0.056 & 0.065 & 0.080 & 187291.567 & 21546.0215 & 20786.34266 & 0.01190 & 0.31671 & 200.90633 & 13.679 & 3572.2219 & 0.015 & 14.781 & 36812.807 \\
\hline Median & .085 & 0.000 & 0.000 & 0.000 & 30106.0943 & 653.20 & $\mathrm{o}$ & 0.00049 & 0.00000 & 0.38442 & 0.445 & & 0.068 & 0.000 & 32089.832 \\
\hline Mode & -2.050 & 0.000 & 0.000 & 0.000 & $\frac{0}{0}$ & & o & 0.00000 & 0.00000 & 0.00000 & 0.000 & o & 0.000 & 0.000 & o \\
\hline $\begin{array}{l}\text { Standard } \\
\text { Deviation }\end{array}$ & 1.319 & 0.822 & 0.955 & 1.181 & 2758977.07 & 317392.717 & 306201.948 & 0.17527 & 4.66544 & 2959.53509 & 201.506 & 52622.115 & 0.224 & 217.742 & 542286.51 \\
\hline $\begin{array}{l}\text { Sample } \\
\text { Variance }\end{array}$ & 1.738 & 0.676 & 0.911 & 1.396 & $7.61195^{\mathrm{E}+1}$ & $1.00738 \mathrm{E}+1$ & 937596329.8 & 0.0307 & 21.76630 & 8758847.925 & 40604.6 & $27690870 . \mathrm{ZZ}$ & 0.050 & 47411.480 & $2.9407 \mathrm{E}+11$ \\
\hline Kurtosis & 80.212 & 126.361 & 148.841 & 4.311 & 5.15645097 & 42.63340811 & 69.13406489 & 33.61051 & 199.86800 & 216.98738 & 101.610 & 216.993086 & 1.042 & 61.621 & 77.3618597 \\
\hline Skewne & 7.292 & 10.368 & 37 & 089 & 6.508652344 & 6.170453969 & -0.233987248 & 77219 & 94168 & \begin{tabular}{|l|l|}
-14.73028 \\
\end{tabular} & -9.973 & -14.7305703 & 1.388 & -6.677 & 5.65140206 \\
\hline Range & 17.511 & 11.712 & 15.269 & 18.259 & 29077150.47 & 2720052.5 & 5630668.75 & 2.53875 & 69.80553 & 43733.69129 & 2443.378 & 775677.968 & 1.000 & 2781.803 & 5652902.88 \\
\hline Minimu & -2.436 & -1.078 & & -1.111 & o & 0 & 32362.5 & -1.14523 & 2.40489 & -43594.20751 & -2213.652 & -775171.945 & 0.000 & -2136.977 & o \\
\hline Maximum & 15.075 & 10.634 & 12.836 & 17.148 & 29077150.47 & 2720052.5 & 2698306.25 & 1.39351 & 67.40064 & 139.48378 & 229.726 & 506.023039 & 1.000 & 644.826 & 5652902.88 \\
\hline Sum & 1.135 & 29.215 & 20.976 & 17.491 & 181410182.7 & 17280722.25 & \begin{tabular}{|c|}
3699305.75 \\
\end{tabular} & $\begin{array}{ll}5.97237 \\
\end{array}$ & 83.56393 & -43196.48861 & -4006.407 & -776438.92 & 37.361 & -3534.614 & 55204121.5 \\
\hline Count & 217 & 217 & 217 & 217 & 217 & 217 & 217 & 217 & 217 & 217 & 217 & 217 & 117 & $=$ & \\
\hline
\end{tabular}

Table 2 Descriptive Statistics of Cement Sector

\begin{tabular}{|c|c|c|c|c|c|c|c|c|c|c|c|c|c|c|c|}
\hline & AR & CCMt & CEBItMt & CDMt & NFMt & CtMt & CtMtCCMt & CACMt & CIMt & $\mathrm{OL}$ & FL & TL & LR & LRCCMt & WACC \\
\hline Mean & -0.0022 & 0.3485 & 0.1482 & 466.5387 & 2314056.378 & 68134.95794 & 45701.66902 & 0.0123 & 15.9685 & 3.6409 & -26.6954 & -31.2389 & 0.2513 & -8.0480 & 322330.023 \\
\hline $\begin{array}{l}\text { Standard } \\
\text { Error } \\
\end{array}$ & 0.1090 & 0.1812 & 0.0936 & 431.7426 & 487538.3145 & 27402.81013 & 61236.35743 & 0.0042 & 15.8921 & 1.3569 & 29.6055 & 30.0958 & 0.0269 & 9.6120 & 48541.7605 \\
\hline Median & -0.3200 & 0.0000 & 0.0023 & 0.0000 & 352285.5728 & 6628.850982 & o & 0.0024 & 0.0023 & 0.7454 & 0.0000 & -0.0261 & 0.2399 & 0.0000 & 101714.839 \\
\hline Mode & -0.3300 & 0.0000 & 0.0000 & 0.0000 & $\mathrm{o}$ & $\mathrm{o}$ & $\mathrm{o}$ & 0.0000 & 0.0000 & 0.0000 & 0.0000 & 0.0000 & 0.0000 & 0.0000 & 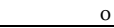 \\
\hline \begin{tabular}{|l|} 
Standard \\
Deviation
\end{tabular} & 1.2234 & 2.0338 & 1.0501 & 46.2988 & 5472604.008 & 307595.7808 & 687376.4074 & 0.0473 & 178.388 & 15.2312 & 332.3208 & 337.8246 & 0.3016 & 107.8947 & 544879.91 \\
\hline \begin{tabular}{|l} 
Sample \\
Variance \\
\end{tabular} & 1.4967 & 4.1365 & 1.1028 & 23486611.910 & $2.99494 \mathrm{E}+13$ & 94615164390 & $4.72486 \mathrm{E}+11$ & 0.0022 & 31822.3 & 231.99 & 110437.1 & 114125.48 & 0.0910 & 11641.269 & $2.9689 \mathrm{E}+11$ \\
\hline Kurtosis & 12.385 & 74.052 & 94.6760 & 124.8990 & 22.11551124 & 103.042707 & 78.65718542 & 45.9330 & 125.993 & 36.3703 & 123.3702 & 114.8071 & 5.8413 & 42.1837 & 9.26285538 \\
\hline Skewness & 3.0350 & 8.0927 & 9.1795 & 11.1547 & 4.168285445 & 9.755675658 & 7.183158924 & 5.7494 & 11.2245 & 5.6346 & -11.0446 & -10.5172 & -1.3280 & -4.7545 & 2.91946824 \\
\hline Range & 8.4507 & 21.595 & 12.5559 & 54319.0443 & 41214663.45 & 3329072.727 & 9765029.545 & 0.5211 & 2003.59 & 141.6478 & 3983.85 & 3944.6518 & 2.2498 & 1224.6454 & 2976581.32 \\
\hline
\end{tabular}




\begin{tabular}{|c|c|c|c|c|c|c|c|c|c|c|c|c|c|c|c|}
\hline \begin{tabular}{|l|} 
Minimum \\
\end{tabular} & -1.3312 & -1.4756 & \begin{tabular}{|l|}
-1.5068 \\
\end{tabular} & -0.2564 & -529875.455 & $\mathrm{o}$ & -2966880.165 & -0.1011 & -1.14 & -22.3630 & -3708.33 & -3708.333 & \begin{tabular}{|l|}
-1.2667 \\
\end{tabular} & -914.1729 & -84366.775 \\
\hline Maximum & 7.1195 & 20.119 & 11.0492 & 54318.7879 & 40684788 & 3329072.727 & 6798149.38 & 0.4200 & 2002.45 & 119.2849 & 275.52 & 236.3185 & 0.9832 & 310.4725 & 2892214.55 \\
\hline Sum & -0.2760 & 43.911 & 18.6671 & 58783.8727 & 291571103.6 & 8585004.7 & 5758410.297 & 1.5455 & 2012.03 & 458.7485 & -3363.62 & -3936.099 & 31.662 & -1014.049 & 40613582.9 \\
\hline Count & 126 & 126 & 126 & 126 & 126 & 126 & 126 & 126 & 126 & 126 & 126 & 126 & 126 & 126 & 126 \\
\hline
\end{tabular}

Table 3 Descriptive Statistics of Fertilizer Sector

\begin{tabular}{|c|c|c|c|c|c|c|c|c|c|c|c|c|c|c|c|}
\hline & AR & CCMt & CEBItMt & CDMt & NFMt & CtMt & CtMtCCMt & CACMt & CIMt & $\mathrm{OL}$ & FL & $\mathrm{TL}$ & LR & LRCCMt & WACC \\
\hline Mean & -0.0106 & 0.0074 & 0.0556 & 0.0043 & 636569.59 & 85491.74 & -4641.98 & 0.0012 & 0.44674 & 1.0000 & 16.679 & 0.4337 & 0.1955 & 8.1098 & 3763733.43 \\
\hline $\begin{array}{l}\text { Standard } \\
\text { Error } \\
\end{array}$ & .0813 & 0.0104 & 0.0540 & 0.0024 & 188844.42 & 42562.61 & 3544.572 & 0.0015 & 0.44785 & 0.2501 & 17.529 & 0.7746 & 0.0299 & 16.0096 & 822090.907 \\
\hline Median & -0.0980 & 0.0000 & 0.0000 & 0 & 74466.2349 & 1378.679 & $\mathrm{o}$ & 0 & 0 & 0.6316 & 0.9577 & 0.6162 & 0.1577 & $\mathrm{O}$ & 2523845.56 \\
\hline Mode & -0.1900 & 0.0000 & 0.0000 & o & $\mathrm{O}$ & o & $\mathrm{o}$ & o & 0 & 0.0000 & $\mathrm{O}$ & $\mathrm{o}$ & $\mathrm{O}$ & $\mathrm{o}$ & 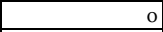 \\
\hline $\begin{array}{l}\text { Standard } \\
\text { Deviation }\end{array}$ & 0.4945 & 0.0630 & 0.3286 & 0.0147 & $1148695 \cdot 77$ & 258898.2 & 21560.79 & 0.0089 & 2.72417 & 1.5211 & 106.62 & 4.7117 & 0.1821 & 97.3824 & 5000583.76 \\
\hline \begin{tabular}{|l|} 
Sample \\
Variance \\
\end{tabular} & 0.2446 & 0.0040 & 0.1080 & 0.0002 & $1.3195 \mathrm{E}+12$ & $6.7 \mathrm{E}+10$ & $4.65 \mathrm{E}+08$ & 8E-05 & 7.42112 & 2.3137 & 11369 & 22.2 & 0.0332 & $9483 \cdot 34$ & $2.5006 \mathrm{E}+13$ \\
\hline Kurtosis & 0.7947 & 26.4220 & 36.8374 & 20.638 & 3.30020663 & 15.50172 & 26.55863 & 14.797 & 36.9977 & 5.9476 & 36.442 & 28.054 & -0.149 & 18.6577 & 2.64903433 \\
\hline Skewness & 0.7442 & 4.5656 & 6.0634 & 4.2602 & 2.02155328 & 4.020568 & -5.04952 & 0.756 & 6.08249 & 2.0174 & 6.0126 & -4.9705 & 0.8516 & 3.05205 & 1.77956574 \\
\hline Range & 2.2535 & 0.4673 & 2.0473 & 0.086 & 4234412.48 & 1224904 & 125131.5 & 0.0718 & 16.6428 & 8.1942 & 693.27 & 29.882 & 0.6176 & 748.286 & $17925004 \cdot 3$ \\
\hline Minimum & -0.9606 & -0.1160 & -0.0487 & -0.0057 & $\mathrm{o}$ & o & -122346 & -0.0325 & -0.0736 & -1.126 & -47.77 & -25.741 & 0 & -256.008 & $\mathrm{o}$ \\
\hline Maximum & 1.2929 & 0.3513 & 1.9986 & 0.0803 & 4234412.48 & 1224904 & 2785.509 & 0.0393 & 16.5692 & 7.0676 & 645.51 & 4.1406 & 0.6176 & 492.278 & $17925004 \cdot 3$ \\
\hline Sum & -0.3908 & 0.2726 & 2.0569 & 0.159 & 23553074.8 & 3163194 & -171753 & 0.043 & 16.5296 & 36.999 & 617.14 & 16.049 & 7.2331 & 300.063 & 139258137 \\
\hline Count & 37 & 37 & 37 & 37 & 37 & 37 & 37 & 37 & 37 & 37 & 37 & 37 & 37 & 37 & 37 \\
\hline
\end{tabular}

\subsection{Correlation Matrix}

Table 4 indicate that in chemical sector net financing to lagged market value has $\mathrm{r}=0.21$ with abnormal return and lagged cash values to lagged market values crossed by change in cash to lagged market value $r=0.17$ to abnormal return and lagged cash values to lagged market values has highly significant relationship of 0.76 to abnormal return. Table 5 indicates that change in dividend to lagged market value has 0.31 degree of correlation to abnormal return. Net financing to lagged market value has 0.25 degree of relationship to abnormal return.

Table 4 Correlation Matrix for Chemical Sector

\begin{tabular}{|c|c|c|c|c|c|c|c|c|c|c|c|c|c|c|c|}
\hline & AR & CCMt & CEBItMt & CDMt & NFMt & CtMt & CtMtCCMt & CACMt & CIMt & $\mathrm{OL}$ & FL & $\mathrm{TL}$ & LR & LRCCMt & WACC \\
\hline CCMt & 0.01 & 1.00 & & & & & & & & & & & & & \\
\hline CEBItMt & 0.09 & 0.03 & 1.00 & & & & & & & & & & & & \\
\hline CDMt & -0.03 & 0.01 & 0.00 & 1.00 & & & & & & & & & & & \\
\hline CtMt & 0.06 & 0.02 & 0.07 & 0.06 & 0.66 & 1.00 & & & & & & & & & \\
\hline CtMtCCMt & 0.18 & 0.23 & 0.07 & 0.04 & 0.08 & 0.03 & 1.00 & & & & & & & & \\
\hline CACMt & -0.03 & 0.06 & 0.22 & 0.03 & 0.32 & 0.66 & -0.07 & 1.00 & & & & & & & \\
\hline TL & -0.07 & -0.07 & 0.01 & 0.00 & -0.04 & 0.01 & 0.00 & -0.01 & 0.01 & 1.00 & -0.01 & 1.00 & & & \\
\hline LR & -0.04 & 0.01 & -0.03 & -0.05 & 0.06 & -0.08 & -0.06 & -0.07 & -0.06 & 0.05 & 0.01 & 0.04 & 1.00 & & \\
\hline LRCCMt & 0.00 & 0.01 & 0.01 & 0.01 & 0.05 & 0.03 & 0.00 & 0.01 & 0.01 & $\mid-0.01$ & 0.02 & -0.01 & -0.10 & 1.00 & \\
\hline WACC & 0.06 & 0.02 & -0.03 & 0.11 & 0.63 & 0.22 & 0.00 & 0.02 & 0.02 & 0.01 & -0.11 & 0.01 & 0.21 & 0.09 & 1.00 \\
\hline
\end{tabular}

Table 5 Correlation Matrix for Cement Sector

\begin{tabular}{|c|c|c|c|c|c|c|c|c|c|c|c|c|c|c|c|}
\hline & AR & CCMt & CEBItMt & CDMt & NFMt & CtMt & CtMtCCMt & CACMt & CIMt & $\mathrm{OL}$ & FL & $\mathrm{TL}$ & LR & LRCCMt & WACC \\
\hline CCMt & 0.10 & 1.00 & & & & & & & & & & & & & \\
\hline CEBItMt & 0.00 & 0.00 & 1.00 & & & & & & & & & & & & \\
\hline CDMt & 0.31 & $\mid-0.02$ & -0.02 & 1.00 & & & & & & & & & & & \\
\hline CtMt & 0.06 & 0.04 & 0.89 & 0.02 & 0.37 & 1.00 & & & & & & & & & \\
\hline CtMtCCMt & 0.06 & 0.89 & -0.34 & -0.01 & 0.17 & $|-0.29|$ & 1.00 & & & & & & & & \\
\hline CACMt & -0.15 & 0.15 & 0.31 & -0.06 & 0.16 & 0.36 & 0.04 & 1.00 & & & & & & & \\
\hline $\mathrm{TL}$ & 0.00 & 0.06 & 0.01 & 0.02 & 0.02 & 0.02 & 0.05 & -0.08 & 0.01 & 0.01 & 0.97 & 1.00 & & & \\
\hline LR & 0.03 & -0.13 & -0.43 & -0.05 & 0.02 & -0.42 & 0.06 & -0.21 & -0.04 & -0.05 & -0.01 & -0.01 & 1.00 & & \\
\hline LRCCMt & 0.04 & 0.01 & 0.01 & 0.01 & 0.06 & 0.02 & 0.00 & -0.01 & 0.01 & 0.02 & 0.31 & 0.31 & 0.04 & 1.00 & \\
\hline WACC & 0.05 & $\mid-0.04$ & 0.32 & -0.01 & 0.27 & 0.37 & -0.13 & 0.07 & -0.04 & $|-0.04|$ & 0.03 & 0.04 & 0.01 & 0.00 & 1.00 \\
\hline
\end{tabular}

Significant at $5 \%$ level

Table 6 indicate that net financing to lagged market value has positive relationship to abnormal 
return in chemical sector with $r=0.37$ significant at $p=0.05$ and change in total assets net of cash to lagged market value also has -0.41 significant at $\mathrm{p}<0.05$ negative relationship to abnormal return. More over operating leverage has positive relationship to abnormal and financial leverage and leverage ratio to change in cash crossed by lagged market values has negative as well as total leverage and weighted average cost of capital has positive degree of relationship to abnormal return.

\subsection{Regression Models}

Table 7 indicates that change in total assets net of cash to lagged market value has significant negative impact on abnormal return at $\mathrm{p}<0.01$ as expressed by OLS, Fixed effect as well as in random effect behavior. In fertilizer only fixed effect exist at $\mathrm{p}<0.1$ on abnormal return. Change in dividend to lagged market value has positive significant impact on abnormal return at $\mathrm{p}=0.01$ in cement sector in each model but in chemical sector OLS and random effect model has negative impact whereas fixed effect has positive effect. Lagged cash values to lagged market has positive impact at $\mathrm{p}=0.01$ in chemical sector. Lagged cash values to lagged market values crossed by change in cash to lagged market value has significant impact in chemical sector but fertilizer sector is visualized in OLS and random effect at $\mathrm{p}=0.10$. Financial leverage has negative impact on fertilizer sector at $\mathrm{p}=0.1$ and in chemical sector $\mathrm{p}<0.05$. Net Financing to lagged market value has positive impact $\mathrm{p}<0.05$ in cement sector and in fertilizer sector but no impact in chemical sector. Operating Leverage has positive significant impact $\mathrm{p}<0.01$ in fertilizer sector only. R2 values indicate that these variables are significant explanatory variable in fertilizer and chemical sectors.

Table 6 Correlation Matrix of Fertilizer Sector

\begin{tabular}{|l|l|l|l|l|l|l|l|l|l|l|l|l|l|l|l|l|}
\hline & AR & CCMt & CEBITMt & CDMt & NFMt & CtMt & CtMtCCMt & CACMt & CIMt & OL & FL & TL & LR & LRCCMt & WACC \\
\hline AR & 1.00 & & & & & & & & & & & & & & & \\
\hline CCMt & -0.09 & 1.00 & & & & & & & & & & & & & & \\
\hline CEBItMt & 0.01 & 0.93 & 1.00 & & & & & & & & & & & \\
\hline CDMt & 0.00 & -0.26 & -0.03 & 1.00 & & & & & & & & & & & \\
\hline NFMt & 0.38 & -0.06 & 0.17 & 0.59 & 1.00 & & & & & & & & & & & \\
\hline CtMt & 0.17 & -0.33 & -0.04 & 0.89 & 0.69 & 1.00 & & & & & & & & & & \\
\hline CtMtCCMt & -0.34 & 0.38 & 0.07 & -0.64 & -0.67 & -0.88 & 1.00 & & & & & & & & \\
\hline CACMt & -0.42 & 0.12 & 0.05 & 0.40 & 0.04 & 0.13 & 0.32 & 1.00 & & & & & & \\
\hline CIMt & 0.02 & 0.92 & 1.00 & -0.05 & 0.16 & -0.05 & 0.06 & 0.01 & 1.00 & & & & & & \\
\hline OL & 0.19 & -0.10 & -0.10 & 0.22 & -0.02 & 0.19 & -0.10 & 0.18 & -0.11 & 1.00 & & & & \\
\hline FL & -0.09 & -0.02 & -0.03 & -0.03 & -0.07 & -0.02 & 0.03 & 0.01 & -0.03 & -0.10 & 1.00 & & \\
\hline TL & 0.10 & -0.02 & -0.01 & 0.07 & 0.08 & 0.06 & -0.06 & 0.00 & -0.02 & 0.36 & -0.92 & 1.00 & & & \\
\hline LR & 0.11 & 0.32 & 0.34 & 0.03 & 0.49 & 0.02 & 0.03 & 0.12 & 0.33 & 0.06 & -0.02 & 0.08 & 1.00 & & \\
\hline LRCCMt & -0.10 & 0.02 & -0.01 & 0.00 & -0.13 & -0.03 & 0.03 & 0.00 & -0.01 & -0.03 & 0.83 & -0.80 & 0.06 & 1.00 & \\
\hline WACC & 0.18 & -0.23 & -0.04 & 0.43 & 0.52 & 0.60 & -0.57 & -0.03 & -0.04 & 0.03 & -0.06 & 0.09 & 0.05 & -0.29 & 1.00 \\
\hline
\end{tabular}

Table 7 OLS, Fixed Effect and Random Effect in Cement, Fertilizer and Chemical Sector

\begin{tabular}{|c|c|c|c|c|c|c|c|c|c|}
\hline & \multicolumn{3}{|l|}{ Cement } & \multicolumn{3}{|l|}{ Fertilizer } & \multicolumn{3}{|l|}{ Chemical } \\
\hline & OLS & Fixed effect & Random Effect & OLS & Fixed Effect & Random Effect & OLS & $\begin{array}{l}\text { Fixed } \\
\text { effect }\end{array}$ & $\begin{array}{l}\text { Random } \\
\text { Effect }\end{array}$ \\
\hline $\mathrm{C}$ & -0.165262 & -0.220954 & -0.165262 & $-0.14375^{8}$ & -0.210643 & -0.143758 & -0.05613 & -0.094081 & -0.05613 \\
\hline p-value & 0.3204 & 0.2594 & 0.3366 & 0.3049 & 0.3111 & 0.3174 & 0.4249 & 0.2548 & 0.4451 \\
\hline CACMT & -4.405112 & -3.899884 & -4.405112 & -42.7069 & -48.47508 & -42.7069 & -2.080546 & -1.853921 & -2.080546 \\
\hline $\mathrm{p}$-value & 0.141 & 0.2374 & 0.1545 & 0.1145 & $0.0968^{*}$ & 0.1237 & $0.00^{* * *}$ & $0.0001^{* * *}$ & $0.00^{* * *}$ \\
\hline СCMT & 0.157796 & 0.137478 & 0.157796 & -2.560336 & -2.16734 & -2.560336 & -0.026715 & -0.00958 & -0.026715 \\
\hline $\mathrm{p}$-value & 0.3494 & 0.4486 & 0.3655 & 0.6648 & 0.7268 & 0.673 & 0.6825 & 0.8935 & 0.6955 \\
\hline CDMT & 0.0000763 & 0.000085 & 0.0000763 & -8.070432 & -7.503018 & -8.070432 & -0.003843 & 0.009267 & -0.003843 \\
\hline $\mathrm{p}$-value & $0.0006^{* * *}$ & $0.0005^{* * *}$ & $0.0009^{* * *}$ & 0.631 & 0.6707 & 0.6399 & 0.9309 & 0.8498 & 0.9339 \\
\hline CEBITMT & -0.188717 & -0.187192 & -0.188717 & -18.28941 & -8.571451 & -18.28941 & 0.157125 & 0.164571 & 0.157125 \\
\hline $\mathrm{p}$-value & 0.4399 & 0.4638 & 0.4552 & 0.494 & 0.8178 & 0.5052 & $0.0062^{* * *}$ & $0.0087^{* * *}$ & $0.0088^{* * *}$ \\
\hline CIMT & $-3.74 \mathrm{E}-04$ & $-3.97 \mathrm{E}-04$ & $-3.74 \mathrm{E}-04$ & 2.244321 & 1.065661 & 2.244321 & 0.247282 & 0.247262 & 0.247282 \\
\hline p-value & 0.5229 & 0.5318 & 0.5368 & 0.4827 & 0.8108 & 0.4941 & $0.00^{* * *}$ & $0.00^{* * *}$ & $0.00^{* * *}$ \\
\hline CTMT & $4.46 \mathrm{E}-\mathrm{O} 7$ & $4.41 \mathrm{E}-\mathrm{O} 7$ & $4.46 \mathrm{E}-\mathrm{O} 7$ & $3.03 \mathrm{E}-06$ & 0.00000221 & 0.00000303 & $-2.56 \mathrm{E}-\mathrm{O} 7$ & $2.59 \mathrm{E}-\mathrm{O} 7$ & $-2.56 \mathrm{E}-07$ \\
\hline $\mathrm{p}$-value & 0.6154 & 0.6583 & 0.6272 & 0.1843 & 0.5471 & 0.1956 & 0.3795 & 0.5034 & 0.4004 \\
\hline СТМТССМТ & $-3.97 \mathrm{E}-07$ & $-3.41 \mathrm{E}-07$ & -0.00000039 & 0.0000449 & 0.0000379 & 0.0000449 & $-6.01 \mathrm{E}-07$ & $-4.05 \mathrm{E}-07$ & $-6.01 \mathrm{E}-07$ \\
\hline $\mathrm{p}$-value & 0.4483 & 0.5446 & 0.4634 & 0.0757 & 0.3289 & $0.0831^{*}$ & $0.0016^{* * *}$ & $0.0609^{* *}$ & $0.0026^{* * *}$ \\
\hline $\mathrm{FL}$ & -0.00073 & -0.000429 & -0.00073 & -0.004499 & -0.005902 & -0.004499 & -0.000617 & -0.000634 & -0.000617 \\
\hline $\mathrm{p}$-value & 0.5987 & 0.7725 & 0.6108 & $0.0687^{* * *}$ & $0.0719^{* * *}$ & $0.0757^{* * *}$ & $0.0183^{* *}$ & $0.027^{* *}$ & $0.0239^{* *}$ \\
\hline LR & 0.096748 & -0.029828 & 0.096748 & -0.61518 & -0.44282 & -0.61518 & -0.114929 & -0.199994 & -0.114929 \\
\hline $\mathrm{p}$-value & 0.8115 & 0.9494 & 0.8176 & 0.4208 & 0.6482 & 0.4329 & 0.6481 & 0.553 & 0.6623 \\
\hline LRCCMT & $3.90 \mathrm{E}-\mathrm{O} 4$ & $3.16 \mathrm{E}-\mathrm{O} 4$ & $3.90 \mathrm{E}-\mathrm{O} 4$ & 0.000203 & 0.000364 & 0.000203 & -0.000069 & -0.000045 & -0.0000696 \\
\hline
\end{tabular}


Review of Economics and Development Studies, Vol. 6 (1) 2020 ,

153-166

\begin{tabular}{|c|c|c|c|c|c|c|c|c|c|}
\hline p-value & 0.7008 & 0.7796 & 0.7103 & 0.9191 & 0.8621 & 0.9212 & 0.7726 & 0.8607 & 0.7822 \\
\hline NFMT & $5.2 \mathrm{E}-\mathrm{o} 8$ & $8.29 \mathrm{E}-08$ & 0.000000052 & $4.25 \mathrm{E}-07$ & $4.45 \mathrm{E}-\mathrm{O} 7$ & 0.000000425 & $2.81 \mathrm{E}-\mathrm{o} 8$ & $2.39 \mathrm{E}-08$ & $2.81 \mathrm{E}-\mathrm{o} 8$ \\
\hline $\mathrm{p}$-value & $0.0268^{* *}$ & $0.006^{* * *}$ & $0.0322^{* *}$ & $0.0096^{* * *}$ & $0.0389^{* *}$ & $0.0114^{*}$ & 0.421 & 0.5722 & 0.4413 \\
\hline $\mathrm{OL}$ & 0.001549 & 0.000771 & 0.001549 & 0.217091 & 0.211024 & 0.217091 & -0.000619 & -0.000968 & -0.000619 \\
\hline $\mathrm{p}$-value & 0.8379 & 0.925 & 0.8432 & 0.0052 & 0.0128 & 0.0063 & 0.8043 & 0.7199 & 0.8126 \\
\hline $\mathrm{TL}$ & $5 \cdot 38 \mathrm{E}-04$ & $2.43 \mathrm{E}-\mathrm{O} 4$ & 5.38E-04 & -0.105136 & -0.136382 & -0.105136 & 0.0000328 & 0.0000524 & 0.0000328 \\
\hline $\mathrm{p}$-value & 0.6955 & 0.8677 & 0.7051 & 0.1042 & 0.1023 & 0.113 & 0.8155 & 0.7299 & 0.8233 \\
\hline WACC & -4.97 E-09 & $3.16 \mathrm{E}-08$ & $-4.97 \mathrm{E}-09$ & $-1.13 \mathrm{E}-\mathrm{o} 8$ & $1.14 \mathrm{E}-08$ & $-1.13 \mathrm{E}-\mathrm{o} 8$ & $6.39 \mathrm{E}-08$ & $7.24 \mathrm{E}-08$ & $6.39 \mathrm{E}-08$ \\
\hline p-value & 0.9814 & 0.9176 & 0.982 & 0.6556 & 0.7965 & 0.664 & 0.6426 & 0.6992 & 0.657 \\
\hline R-squared & 0.208216 & 0.256934 & 0.208216 & 0.59091 & 0.61797 & 0.59091 & 0.690325 & 0.705565 & 0.690325 \\
\hline Adjusted R 2 & 0.108352 & 0.052212 & 0.108352 & 0.318184 & 0.257164 & 0.318184 & 0.668756 & 0.644362 & 0.668756 \\
\hline $\begin{array}{l}\text { Cross } \\
\text { Section }\end{array}$ & 14 & 14 & 14 & 4 & 4 & 4 & 24 & 24 & 24 \\
\hline Observations & 126 & 126 & 126 & 36 & 36 & 36 & 216 & 216 & 216 \\
\hline
\end{tabular}

***Significant at $1 \%$ level, ${ }^{* *}$ Significant at $5 \%$ level, * Significant at $10 \%$ level

\section{Conclusion}

The industrial fall has become the most critical issue in the economy of Pakistan in the present era. These downfalls may be due to financial policies incorporated by firms in a traditional manner. Even researchers are trying to investigate the basic determinants which can affect the financial policy of firms in the industrial sector of Pakistan. The purpose of this study is to investigate the relationship and to model the leverage dynamics and corporate financial policies for abnormal return of the firms. This study has taken 10 years balanced panel data for the period 2008-2017 from chemical, cement and fertilizer sector of Pakistan. Moreover in fertilizer sectors negative abnormal returns exist. In this study we are focusing to investigate the changing dynamics of explanatory variables on the firm's abnormal returns to optimize the best corporate financial policies for the industrial sector Pakistan. Results conclude that chemical sector is more growing sector in Pakistan and providing high abnormal returns than cement and fertilizer sector. Results indicate that the returns are positive in chemical sector and in Cement and fertilizer sector returns are negative.

Correlation indicates that in chemical sector net financing to lagged market value has positive correlation with abnormal return and lagged cash values to lagged market values crossed by change in cash to lagged market value has little positivity to abnormal return and lagged cash values to lagged market values has highly significant relationship to abnormal return. Further results for Cement Sector indicate that change in dividend to lagged market value has positive degree of correlation to abnormal return and net financing to lagged market value has positive degree of relationship to abnormal return. Maia (2010) argued in the same manner. For Fertilizer Sector results indicates that net financing to lagged market value has positive relationship to abnormal return and change in total assets net of cash to lagged market value also has negative significant relationship to abnormal return. The study of Dangl and Zechner (2006), Abdullah, Aydemir, Gallmeryer and Hollifield (2006) Faulkender, Flannery, Hankins and Smith (2012) also support our argument as well. Moreover operating leverage has positive relationship to abnormal return leverage ratio to change in cash crossed by lagged market values has negative as well as total leverage and weighted average cost of capital has positive degree of relationship to abnormal return. Aivazian, Ge and Qiu (2005), Cai and Zhang (2011), Johnson, Chebonenko, Cunha, D’Almeida and Spencer (2011) and Obreja (2013) also support this last argument. Further results indicates that change in total assets net of cash to lagged market value has significant negative impact on abnormal return as expressed by OLS, Fixed effect as well as in random effect behavior. In fertilizer only fixed effect exist on abnormal return. Change in dividend to lagged market value has positive significant impact on abnormal return in cement sector in each model but in chemical sector OLS and random effect model has negative impact whereas fixed effect has positive effect. A lagged cash value to lagged market has positive impact in chemical sector. Lagged cash values to lagged market values crossed by change in cash to lagged market value has significant impact in chemical sector but fertilizer sector is visualized in OLS and random effect. Financial leverage has negative impact on fertilizer sector and in chemical sector and our study support to the facts of Riccetti, Russo 
and Gallegati (2016). Net Financing to lagged market value has positive impact in cement sector and in fertilizer sector but no impact in chemical sector. Operating Leverage has positive significant impact in fertilizer sector only as results reported by Frank and Goyal (2015). R2 values indicate that these variables are significant explanatory variable in fertilizer and chemical sectors. $\mathrm{H} 1$ is rejected it is concluded that change in cash to lagged market values has no negative impact on abnormal return and have no significant positive relationship with abnormal return and in the same manner $\mathrm{H} 2$ is rejected that change in EBIT to lagged market values has no positive impact on abnormal return and no significant positive relationship with abnormal returns.

However $\mathrm{H}_{3}$ Change in dividend to lagged market values has a positive impact on abnormal return in cement sector only and also has a significant positive relationship with abnormal return in cement sector only but the same is hypothesis is rejected for other sectors. $\mathrm{H}_{4}$ results indicate that Net Financing to lagged market values has no impact in chemical sector but has a positive significant impact in cement and fertilizer sectors on abnormal return. According to $\mathrm{H}_{5}$ Lagged cash values to lagged market values has a positive impact on abnormal return and also has a significant positive relationship with abnormal return has highly significant relationship to abnormal return in chemical sector as well as $\mathrm{H}_{5}$ has a positive impact on abnormal return in chemical sector only. However results for $\mathrm{H} 6$ indicates that lagged cash values to lagged market values crossed by change in cash to lagged market value has a positive impact on abnormal return and also has a significant negative relationship with abnormal return has a little positive correlation to abnormal return in chemical sector as well as has a significant impact in chemical sector but fertilizer sector is visualized in OLS and Random Effect Model only. According to $\mathrm{H} 7 \mathrm{Change}$ in total assets net of cash to lagged market values has positive impact on abnormal return and also has a significant positive relationship with abnormal return has negative significant relationship to abnormal return in fertilizer sector as well as has a significant negative impact on abnormal return as expressed by OLS, Fixed effect and Random effect models but in fertilizer sector only fixed effect exist on abnormal return. However, H8 indicates that Change in interest to lagged market values has negative impact on abnormal return and also has a significant negative relationship with abnormal return is rejected in all sectors.

As per $\mathrm{H} 9$ results it is concluded that Operating leverage has positive impact on abnormal return and also have a significant negative relationship with abnormal return has a positive relationship to abnormal return and also has a significant positive impact on abnormal return in fertilizer sector only but according to H1o Financial leverage has a positive impact on abnormal return and also has significant negative relationship with abnormal return has a negative correlation with abnormal return in all sectors and also has a negative impact on abnormal return in fertilizer and chemical sectors. H11 is rejected for other sectors except fertilizer sector. H12 indicates that Leverage ratio has a positive impact on abnormal return and also has significant negative relationship with abnormal return but rejected in all sectors. However $\mathrm{H} 13$ indicates that leverage ratio to change in cash crossed by lagged market values has a positive impact on abnormal return and also has significant negative relationship with abnormal return fertilizer sector only. According to H14 the WACC has a positive impact on abnormal return and also has significant negative relationship with abnormal return is rejected for fertilizer sector where the results are in negative domain. Hence it is inferred from this study that modeling the leverage dynamics and corporate financial policies significantly contribute in the firm performance. Hence it is concluded that leverage dynamics are significant contributors in designing the corporate financial policies and have significant impact on the financial performance of the non-financial sector of Pakistan. The practical implication of this study reveals that it is guiding to the industrial policy makers and to the corporate financial managers in developing strategic plans for Non -Financial Sector of Pakistan. 


\section{References}

Abdullah, C., Aydemir, M., Gallmeryer, F. and Hollifield, B. (2006). Financial leverage does not cause the leverage effect. AFA 2007 Chicago Meeting Paper.

Admati,A., Demarzo, P,M., Hellwig, F, M., and Pfleidered, P. (2018). The leverage ratchet effect. The Journal of Finance,.Vol. LXXIII, No. 1.

Aivazian, V., Ge, Y. and Qiu, J. (2005). The impact of leverage on firm investment: Canadian evidence. Journal of Corporate Finance.11(1), 277-291.

Ball, R., Gerakos, J., Linnainmaa, J. T. and Nikolaev, V. (2016). Accurals, cash flows, and operating profitability in the cross section of stock returns. Journal of Financial Economics. 121(1), 28-45.

Bhatti, A. M., Majeed, K., Rehman, I. and Khan, W. A. (2010). Affect of leverage on risk and stock returns: evidence from Pakistani companies. International Research Journal of Finance and Economics. 58,32-49.

Cai, J. and Zhang, Z. (2011). Leverage change, debt overhang, and stock prices. Journal of Corporate Finance. 17(3), 391-402.

Dangl, T. and Zechner, J. (2006). Debt Maturity and the dynamics of leverage. EFA Zurich Meetings Paper.

Duan, Y., Chen, W., Zeng, Q., Liu, Z., (2018). Leverage effect, economic policy uncertainty and realized volatility with regime switching. Physica A. 493. 148-154.

Faulkender, M., Flannery, M. J., Hankins, K. W. and Smith, J. M. (2012). Cash flows and leverage adjustments. Journal of financial Economics, 103(3), 632-646.

Frank, M. Z. and Goyal, V. K. (2015). The Profits-Leverage Puzzle Revisited. Review of Finance. 19(4), $1415-1453$.

Johnson, T. C., Chebonenko, T., Cunha, I., D’Almeida, F. and Spencer, X. (2011). Endogenous leverage and expected stock returns. Finance Research Letters. 8(3), 132-145.

Maia, M. V. (2010). Cash-Flow Risks, Financial Leverage and the Cross Section of equity Return. Publicly accessible Penn Dissertations.161

Modigliani, F. and Miller, M. H. (1958). The cost of capital, corporation finance, and the theory of investment. The American Economic Review. 48(3), 261-297.

Nadarajah, S., Ali, S., Liu, B. and Haung, A. (2016). Stock liquidity, corporate governance and leverage: New panel evidence, Pacific-Basin Finance Journal.

Obreja, L. (2013). Book-to-Market equity, financial leverage, and the cross-section of stock returns. The Review of financial studies. 26 (5), 1146-1189.

Riccetti, L., Russo, A. and Gallegati, M. (2016). Stock market dynamics, leveraged network-based financial accelerator and monetary policy. International Review of Economics and Finance, 43(C). 509-524.

Teng, M., Si, J. and Hachiya, T. (2016). Banking relationship, relative leverage and stock returns in Japan. Pacific-Basin Finance Journa., 40(PA), 86-101.

Yarram, S. R. (2013b). Ownership and financial leverage: Australian evidence. The Asia Pacific Journal of Economics \& Business. 17, 13-2 
Abbreviations to variables

\begin{tabular}{|l|l|}
\hline AR & Abnormal Return \\
\hline CCMt & Change in cash to lagged market values \\
\hline CEBItMt & Change in EBIT to lagged market values \\
\hline CDMt & Change in dividend to lagged market values \\
\hline NFMt & Net Financing to lagged market values \\
\hline CtMt & Lagged cash values to lagged market values \\
\hline CtMtCCMt & $\begin{array}{l}\text { Lagged cash values to lagged market values crossed by change in cash to lagged } \\
\text { market values }\end{array}$ \\
\hline CACMt & Change in total assets net of cash to lagged market values \\
\hline CIMt & Change in interest to lagged market values \\
\hline OL & Operating Leverage \\
\hline FL & Financial Leverage \\
\hline TL & Total Leverage \\
\hline LR & Leverage Ratio \\
\hline LRCCMt & Leverage ratio to change in cash crossed by lagged market values \\
\hline WACC & Weighted average cost of capital \\
\hline
\end{tabular}

